\title{
Landslide susceptibility mapping in eastern hills of Rara Lake, western Nepal
}

\author{
*Padam Bahadur Budha ${ }^{1}$, Kabiraj Paudyal ${ }^{2}$, Motilal Ghimire ${ }^{3}$ \\ ${ }^{1}$ Central Department of Environmental Science, Tribhuvan University, Kirtipur, Kathmandu, Nepal \\ ${ }^{2}$ Central Department of Geology, Tribhuvan University, Kirtipur, Kathmandu, Nepal \\ ${ }^{3}$ Central Department of Geography, Tribhuvan University, Kirtipur, Kathmandu, Nepal \\ (*E-mail: padambudha88@gmail.com)
}

\begin{abstract}
The tendency of occurrences of slope failures in future in an area is landslides susceptibility. This tendency in eastern hills of Rara Lake was analyzed through mapping process. Bivariate statistical index method was used to produce the susceptibility of landslides. Ninety six slope failures were delineated from Google Earth imagery. The ratio of landslide densities of each individual factor classes to that of whole area gave weight values necessary to produce landslide susceptibility index (LSI). East and South facing slopes, gradients of $<30^{\circ}$, elevation of $2000-2800 \mathrm{~m}$, buffers closer to road and streams, grassland and cultivation lands, and lithology of pelitic metamorphic rocks were factor classes with positive weight values. The LSI values ranging from -7.12 to 5.45 were reclassified into five susceptibility classes. Landslide densities of 8.12 and 4.76 per $\mathrm{km}^{2}$ were observed for very high and high susceptible zones. Success rate curve, made from 35 landslides located in the field survey, showed 0.76 portion area under the curve. This gives $76 \%$ overall success rate. Higher susceptible areas are cultivated areas and grasslands, where most houses were located. Thus, knowing the landslide susceptibility of areas, necessary preparedness can be done to reduce the impacts.
\end{abstract}

Keywords: Landslide susceptibility, Mugu, Rara Lake, Statistical Index Method, western Nepal

Paper Received: 08 May 2015

Paper Accepted: 06 February 2016

\section{INTRODUCTION}

Landslides are one of the geological hazards. When the impacts from landslides increase in such a way that the community requires support of outside, it turns out to be the disaster. Such impacts can be reduced when future occurrences of landslides can be predicted. Landslide susceptibility maps could assist in this regard. The landslide susceptibility is the function of the degree of inherent stability of the slope together with the presence of factors capable of reducing the excess strength and ultimately triggering movement (Crozier and Glade 2004). It is the tendency of an area to the occurrence of landslides.

Himalaya is said to be the most active and fragile mountain range in the world (Upreti 2001). Nepal Himalaya is characterised by a high relief, high-intensity monsoon rainfall and earth tremors (Kayastha et al. 2013). Such characteristics make Nepal vulnerable to natural and common hazards such as floods, landslides, debris flows and soil erosion. About 12,000 small and large scale landslides occur in Nepal every year (Bhattarai et al. 2002). Such events are reported in very less amount because of poor information and communication system and/or negligible economic impacts. The problem of landslide is even more aggravated as many of Nepalese villages lie adjacent to the unstable slopes and old landslide scars (Dangol 2002). In central Nepal almost $50 \%$ of road alignment passes through the large landslide area (Hasegawa et al. 2009).
There are ample of studies (Dangol 2002, Ghimire 2010, Kayastha et al. 2012, 2013, Poudyal 2012) on landslide hazard assessment in Nepal Himalaya. Most of the researches were focused on central and eastern Nepal. Literatures on same topics in western Nepal are rare. The Mugu District lies in northwestern part of Nepal. Slope instability is major problems in this district as Climate Change Vulnerability Mapping for Nepal (Ministry of Environment 2010) lists the district as one of top vulnerable district regarding landslide hazards. The problem of landslides is neglected even it exist there for years. Recently constructed roads and airport add supplementary risks to the communities inhabiting in that area. Annually increasing soil erosion and landslide processes are threatening the Rara Lake and rich biodiversity surrounding it. Thus, it is vital to carry out research on landslide susceptibility in the area. With this objective landslide susceptibility of the area was examined.

\section{STUDY AREA}

The study area is located in the Mugu District of western Nepal at longitude of $82^{\circ} 6^{\prime} \mathrm{E}$ to $82^{\circ} 12^{\prime} \mathrm{E}$ and latitude of $29^{\circ} 30^{\prime} \mathrm{N}$ to $29^{\circ} 35^{\prime} \mathrm{N}$. It includes 2 Village Development Committees (VDCs), namely Karkibada and Shreenagar VDC. Most parts of the VDCs make the buffer zone of the Rara National Park (Fig. 1). 


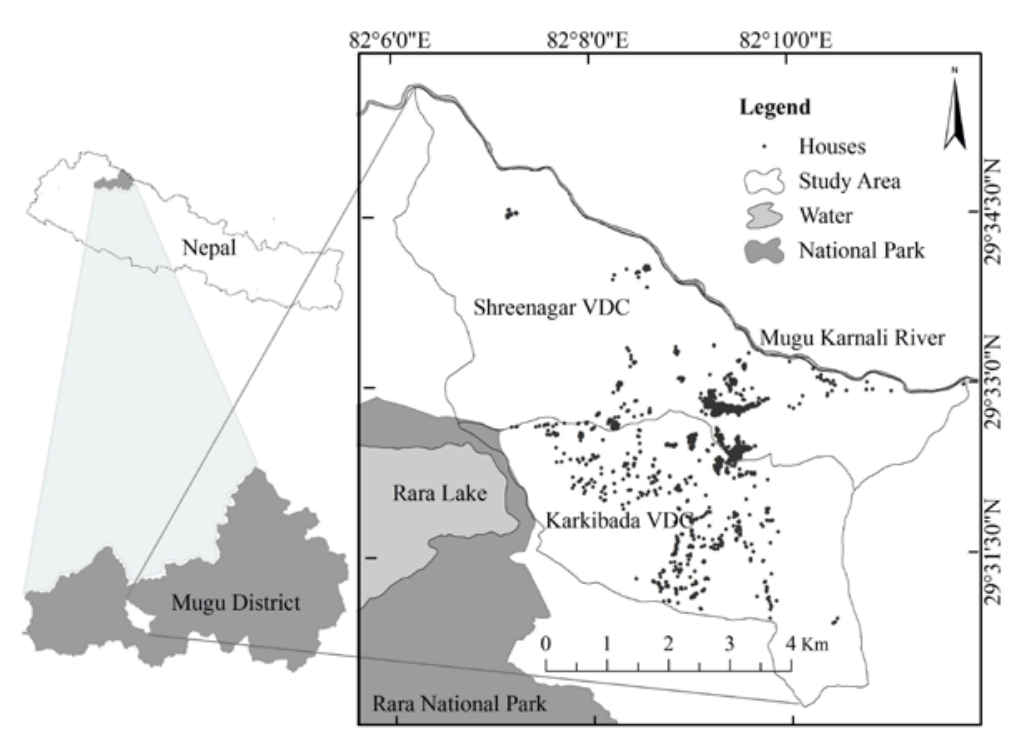

Fig. 1: Location map of study area.

\section{Physiography}

Major portion of the Mugu District belongs to the Fore Himalaya. Main landform development processes of this physiographic region are tectonic upliftment, weathering, erosion and slope failures (Upreti 2001). The province is vulnerable for large landslide occurrences because of less soil on steep slopes that exhibits frequent rock failures (Dahal 2012). The study area comprises uneven terrain and steep slopes. Most slopes are east facing and gradient ranges from $0^{\circ}$ to $72^{\circ}$. It has elevation range from $1,622 \mathrm{~m}$ to $3,460 \mathrm{~m}$.

The Mugu Karnali River forms the border at northern edge of the study area. This snow-fed river is one of the major tributaries of the Karnali River. The Gumgadh River flows in eastern part. The Rara Lake is situated in western border. Here, even small streams, are perennial. Minor gullies and streams become highly destructive in monsoon periods.

\section{Geology}

Geologically, the Mugu District occupies the portion of the Lesser Himalayan Sequence (LHS), the Greater Himalayan Sequence (GHS) and Tethyan Sedimentary Sequence (TSS). The part between the Gamgadhi Bazar and Rara Lake is characterised by poorly deformed very low-grade metamorphic quartzites, belonging to LHS (Fig. 2), showing primary sedimentary structures, such as planar and cross-beddings (Montomoli et al. 2013). Green and black phyllite, quartzite and siliceous gneiss, and mica-chlorite phyllitic schist are major rocks of the region (Arita et al.1984).

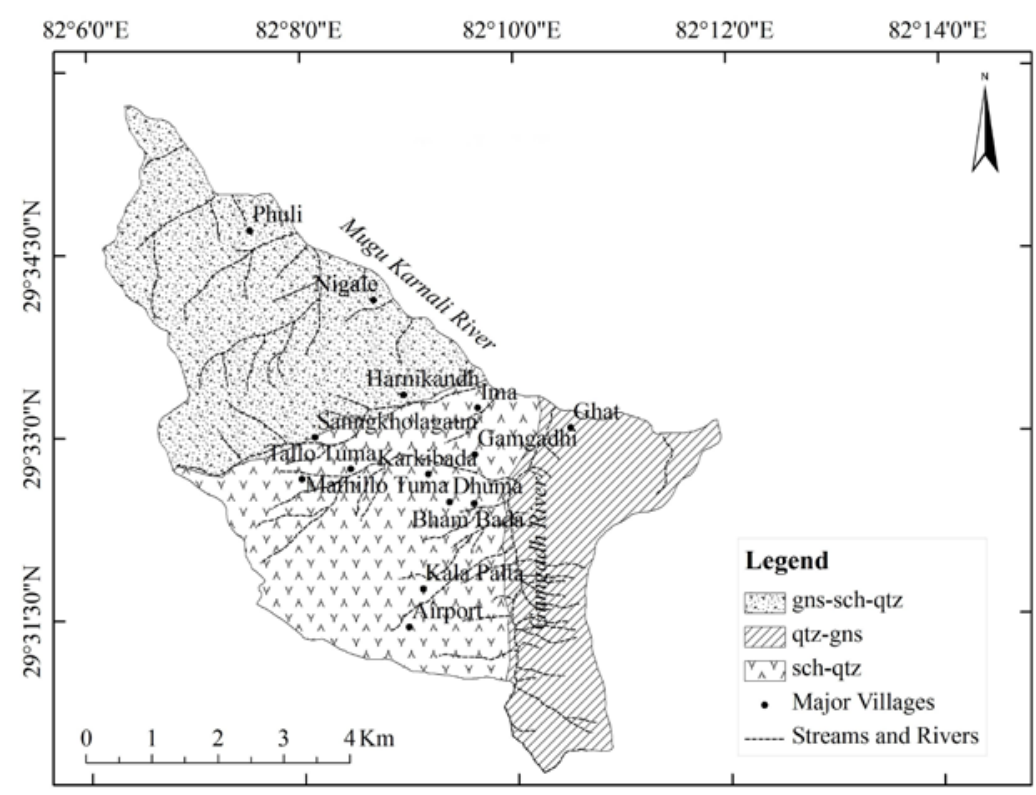

Fig. 2: Geology of study area. 
The Main Central Thrust Zone (MCTZ) passes near the edge of Gamgadhi Bazar that affects the low grade metamorphic quartzite and phyllite, mica-schist, and orthogneiss (Montomoli et al. 2013). Major soil type of the study area are Lithosols (I) ans cambisols (Bd and Bh) and rankers (U), which had medium texture and found mostly in steep (c) and dissected mountainous slopes.

\section{MATERIALS AND METHODS}

\section{Database management}

The data needed for this study included topography, land use classification, terrain morphology, geology, and the locations of landslides. Though, rainfall is considered to be the most important landslide triggering parameter causing soil saturation and a rise in pore-water pressure (Onagh et al. 2012), this analysis does not include precipitation since precipitation was considered relatively uniform throughout the study area. The same can be said of seismicity. All data of the study area were extracted from digital topographic maps (1:50,000 scale) provided by Department of Survey (DoS), Government of Nepal. The data on landuse was modified using Google Earth.

GIS is technology capable of facilitating various functions of geospatial data handling, analysis, and management (Dai and Lee 2002). It has been employed to model and predict landslide susceptibility. Arc-GIS 9.3 mapping software was used for data analysis and mapping procedures in this study.

\section{Digital elevation model (DEM) and its derivatives}

Contours and height points were obtained from digital topographic map of 1:50000 scale provided by DoS. The map has contour interval of $40 \mathrm{~m}$ and supplementary contours are at $20 \mathrm{~m}$ interval. Using this information DEM (Fig. 3) was prepared. The pixel size in DEM was $20 \mathrm{~m}$. The DEM so constructed was used for the analysis of geomorphology as GIS technology permits patterns of slope instability to be analyzed at the scale of the DEM (Ayalew and Yamagishi 2005). Information of elevation, slope angles and slope aspect were derived from DEM.

Elevation map was produced by reclassification of the DEM. The steeper the slope, the greater are landslides (Lee and Min 2001). Most of the flow-like landslides triggered by rainfall appear on roadside slopes of Nepal where slope are mainly between $30^{\circ}$ and $40^{\circ}$, with failures rarely recorded on slopes of $<20^{\circ}$ (Dahal et al. 2006). Gradients were classified into five categories modified after Kayastha et al. (2012) as $0^{\circ}-15^{\circ}$ (gentle slopes), $15^{\circ}-30^{\circ}$ (moderate slopes), $30^{\circ}-45^{\circ}$ (steep slopes), $45^{\circ}-60^{\circ}$ (highly steep slopes), and above $60^{\circ}$ (extremely steep slopes). The facet of hill slope can be related to landslide occurrence by its differential heating and cooling nature. Also, the rainfall quantity varies in wind-ward and leeward side. The aspect considered in the study area was derived from DEM. Aspect were classified into eight classes; namely North, Northeast, East, Southeast, South, Southwest, West and Northwest.

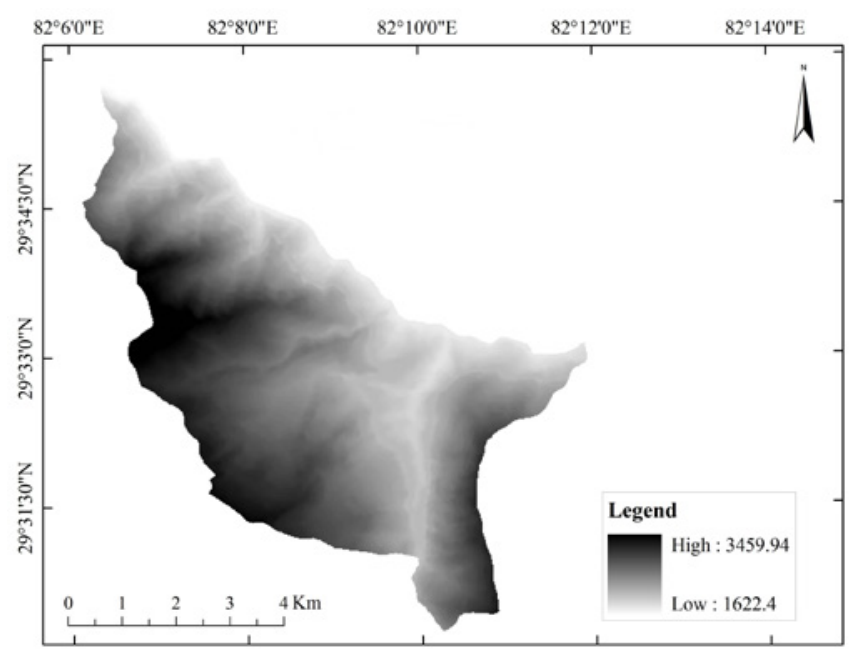

Fig. 3: Digital Elevation Model (DEM) of the study area Land use/cover and buffering of roads and streams.

Land cover/use was also considered important parameter to construct susceptibility (Onagh et al. 2012). Barren slopes are more prone to landslides. Based on field observations, Google Earth image interpretation and the land cover maps provided by the DoS, eight land use classes were identified as airport, bush, cultivation, forest, grassland, river, sand-gravel, and settlement (Fig. 4).

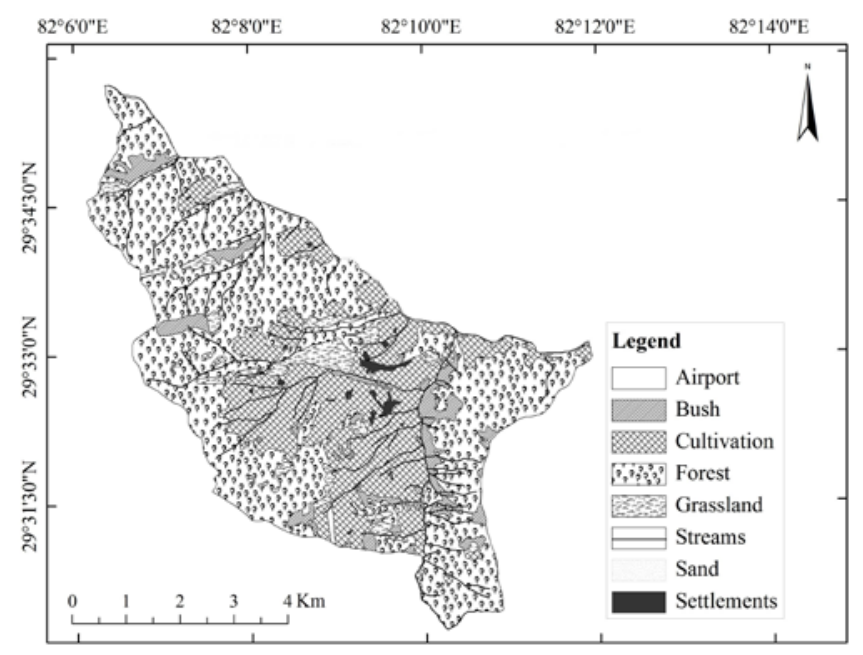

Fig. 4: Land use/cover map of the study area.

The closeness of the slope to drainage structure affects the saturation of the materials. In order to model the influence of runoff on landslide occurrence, distance from drainage was taken into account by Kayastha et al. (2012). Similarly, to include the control of runoff, buffering of streams was considered into four categories: 0-50 m, 50-100 m, 100-200 $\mathrm{m}$, and $>200 \mathrm{~m}$. On the other side, constructed roads decrease in the load on both the topography and on the heel of the slope. Thus, happenings of shallow failures occur along the roadside, both in uphill as well as downhill slope, as major road-problems in Nepal (Dahal et al. 2006). To consider these 
problems, buffering of roads was also classified into four classes: 0-50 m, 50-100 m, 100-200 m, and >200 m.

\section{STATISTICAL INDEX METHOD}

Statistical Index Method develiped by van Westen (1997) was used to optain Susceptibility Map in Arc-GIS environment. This method was also used by Dangol (2002) and Kayastha et al. (2013) in their study in central Nepal. Here, weight value $\left(w_{i j}\right)$ for each parameter (j) class (i) was calculated using Equation 1. A weight value for a parameter class is the natural logarithm of the landslide density in the factor class divided by the landslide density in the entire map (Dangol 2002).

$$
W_{i j}=\ln \left(\frac{f_{i j}}{f}\right)=\ln \left(\frac{A_{i j}^{*}}{A_{i j}} x \frac{A}{A^{*}}\right)
$$

where,

$f_{i j}$ is the landslide density within class $i$ of parameter $j$, $f$ is the landslide density within the entire map, $A_{i j}^{*}$ is the area of landslides in a certain class $i$ of parameter $j$, $A_{i j}$ is the area of a certain class $i$ of parameter $j$, $A^{*}$ is the total area of landslides in the entire map, and $A$ is the total area of the entire map.

The weight values of all parameter classes were combined using Equation 2, to figure out landslide susceptibility index (LSI).

$$
L S I=\sum_{j=1}^{n} W_{i j}
$$

Where, $\mathrm{n}$ is the total number of parameter maps.

Actually, above equation implies that classes in the parameter maps are replaced by their weight value and all the resultant maps are added to obtain the LSI map (Kayastha et al. 2013).

\section{RESULTS AND DISCUSSION}

\section{Landslide inventory and distribution}

The statistical hazard assessment using GIS needs a landslide inventory map, which is used in combination with series of environmental factors (van Westen et al. 1997). Two sets of landslide inventory were prepared in this study. Remote sensing imagery of Google Earth produced 96 landslides (Fig. 5). This set of the landslides were used in making of the landslide susceptibility map. While using landslides inventoried from Google Earth the landslide density of the area was found to be 2.477 per $\mathrm{km}^{2}$, where total area of the research site was 38.76 $\mathrm{km}^{2}$. Total area occupied by the landslides was $0.2544 \mathrm{~km}^{2}$. Most of the landslides were concentrated in cultivated lands and areas devoid of permanent vegetation cover. Of the total landslide area, $77 \%$ was located in Karkibada VDC.

During the field study, 35 landslides were observed. Most of them were located along the cut slope of roads and

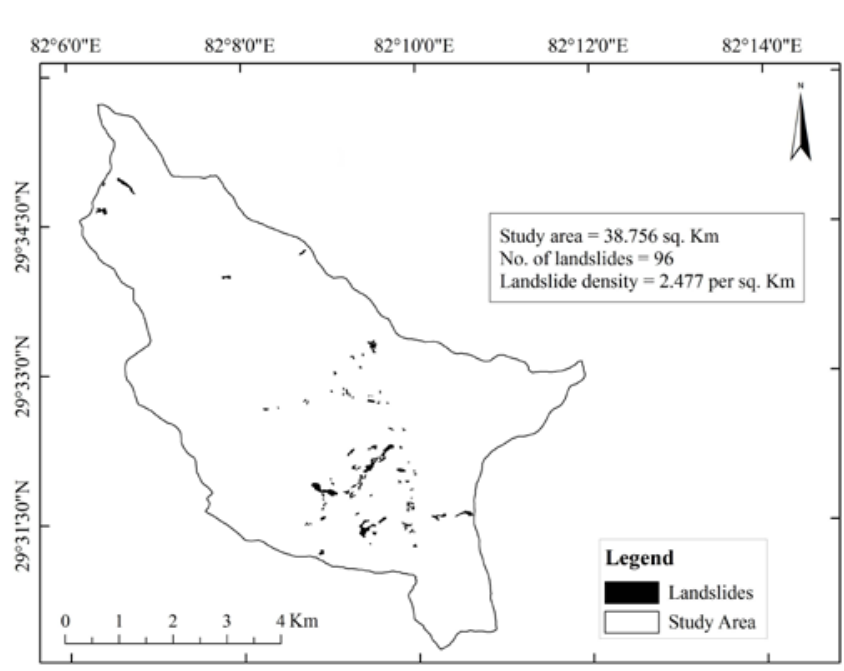

Fig. 5: Landslide inventory of research site.

along narrow stream valleys. This set of landslides was used to draw success rate curve for validation of the susceptibility map produced. Steep slope angle, rugged topography and high influence of surface water were responsible for occurrences of landslides in the area. Anthropogenic activities like haphazard excavation of stones and improper construction of roads were other possible reasons for landslide occurrence.

\section{Factor classes with positive weighted values}

Landslide hazard assessments are based on assumptions that landslides are likely to occur under the same conditions as those under which they occurred in the recent past (Varnes 1984). Weighted value for each parameter classes is given in Table 1. Among eight factor classes of aspect, four had positive weight values (Table 1). These factor classes are east (0.471) south-east $(0.611)$ south $(0.087)$ and south-west $(0.456)$. Fig. in parenthesis represent their weight values and means that these factor classes are responsible for causing landslide occurrence in the future. Mostly, landslides would occur in South and East facets of the slopes. The southern facets of slopes that were formerly cultivated were found to be landslide prone areas (Okino and Satoh 1986) in northern mountains of Rara Lake. North to southeast facing slopes in Kulekhani watershed of central Nepal (Kayastha et al. 2013) and south facing slopes in Kankai watershed of eastern Nepal (Kayastha et al. 2012) had positive weighted values for landslide susceptibility. Aspects as observed in different parts of Himalaya, south and eastern facets have positive weight values as these slopes get higher sunlight and higher rainfall.

In this study, gradient from $0^{\circ}$ to $30^{\circ}$ have found to have positive weight values (Table 1). Results of this study contrasts with that of Kayastha et al. $(2012,2013)$ and Sarkar et al. (2006) ) as their research sites had positive weight values for slopes greater than $25^{\circ}$. These slopes are major cultivated lands and grasslands which are devoid of trees. The intensive use of land on the gentler slopes causes higher disturbance to soils. This leads to slope failures. Hence such slopes tend to be susceptible for landslide hazards 
Susceptibility was high for the altitude of 2,000 to 2,800 $\mathrm{m}$ as shown by their positive weight values in Table 1 . In the field, 20 out of 35 landslides located by Global Positioning System were found between the elevations of 2,000 to 4,000 $\mathrm{m}$. This supported that the altitude from 2,000 to $2,400 \mathrm{~m}$ is highly susceptible to landslides happenings.

Among the major land-use types cultivated lands, grasslands and bushy areas were found to have higher susceptible to landslides. The anchoring effect of permanent vegetation is thus reduced leading to increased soil erosion and thus mass wasting. Also, the lack of forest cover helps in amplifying the effects of precipitation and heat that will weaken the rocks. Thus, these land use types were found to be more susceptible. In a study by Gerrard and Gardner (2002) almost $65 \%$ of landslides were reported from irrigated crop fields as steep cultivated slopes and grasslands possessed landslides of larger size. Dangol (2002) found grasses and bushes as medium hazardous area where as forests and cultivated lands as most hazard prone zones.

Highly weathered metamorphic rocks formed the geology of the study area. As of geological map provided by DOS rock combination with Schist-Quartzite had positive weight values (Table 1). Further, higher number of foliations in rocks, greater degree of rock weathering and soils with less depth exacerbate problem of landslide happenings in this area. Strength of metamorphic rocks is variable, but the planar structures such as foliation represent high risk and rocks like schists, quartzite, and gneiss of Precambrian age pose moderate to medium risks for landslide susceptibility (Nepal Hazard Risk Assessment; Part 1 : Hazard Assessment). A study from the Syangja District in western Nepal showed moderate and high susceptible class related to dolomite, slate and metasandstones of the area (Dangol 2002). Bedding structure, prominent joints, differential rates of weathering and erosion of the sedimentary rocks of the Siwaliks and meta-sedimentary and metamorphic rocks of the Lesser Himalaya (northern part of the Banganga River Basin) were geological characteristics controlling the landslide types and processes (Ghimire 2010). Banded gneiss in Kankai watershed (Kayastha et al. 2012) and phyllite and gneiss of Sikkim (Sarkar et al. 2006) were contributing to landslids and hence produced positive weight values. Areas with lithology of phyllite, schist and gneiss contribute to landslides where high degree of foliation and weathering play crucial role. Lithosol was major soil that covered more than ninty percentage of the study area and hence occupied most landslides.

In portions having high and very high susceptible areas, the role of drainage is most important in determining the susceptibility (Poudyal 2012). Nearer the stream higher the weight values and farther the stream, the weight values decreases. This implied that landslide occurrence probability were higher near to the stream. In comparison to cultivated lands other land-cover types like grassland and forests have higher connectivity of landslides to drainage systems (Gerrard and Gardner 2002). In the field, it was seen that the major landslides ware located near the streams. It was seen in many parts of Shreenagar VDC that the landslide problem was initiated by road construction. Road construction influences the landslide risk by destabilizing slopes and changing the settlement patterns (Lennartz 2013) in mountainous region. The relation between road buffers and landslides is seen positive from zero to $200 \mathrm{~m}$.

Table 1: Table to calculate weighted values.

\begin{tabular}{|c|c|c|c|c|c|c|}
\hline Parameter & Class & Aij & Aij* & $\mathrm{Aij}^{*} / \mathrm{A}^{*}$ & $\mathrm{Aij} / \mathrm{A}$ & Wij \\
\hline \multicolumn{7}{|l|}{ Aspect } \\
\hline & $\mathrm{N}$ & 4.5296 & 0.0108 & 0.042 & 8.556 & -1.013 \\
\hline & $\mathrm{NE}$ & 10.7032 & 0.0688 & 0.270 & 3.621 & -0.021 \\
\hline & E & 6.5456 & 0.0688 & 0.270 & 5.921 & 0.471 \\
\hline & SE & 4.83 & 0.0584 & 0.230 & 8.024 & 0.611 \\
\hline & S & 1.3968 & 0.01 & 0.039 & 27.746 & 0.087 \\
\hline & SW & 0.966 & 0.01 & 0.039 & 40.120 & 0.456 \\
\hline & W & 3.082 & 0.0192 & 0.075 & 12.575 & -0.052 \\
\hline & NW & 3.7088 & 0.0056 & 0.022 & 10.450 & -1.470 \\
\hline & $\mathrm{N}$ & 2.994 & 0.0028 & 0.011 & 12.945 & -1.949 \\
\hline \multicolumn{7}{|l|}{ Gradient } \\
\hline & $0-15$ & 4.9012 & 0.0396 & 0.156 & 7.907 & 0.208 \\
\hline & $15-30$ & 14.9832 & 0.1172 & 0.461 & 2.587 & 0.175 \\
\hline & $30-45$ & 13.396 & 0.0772 & 0.303 & 2.893 & -0.130 \\
\hline & $45-60$ & 5.0488 & 0.0204 & 0.080 & 7.676 & -0.485 \\
\hline & $60-71.6^{\prime}$ & 0.4268 & 0 & 0.000 & 90.806 & 0.000 \\
\hline \multicolumn{7}{|l|}{ Elevation } \\
\hline & $1622.4-2000$ & 6.6688 & 0.0232 & 0.091 & 5.812 & -0.635 \\
\hline & $2000-2400$ & 13.2992 & 0.1324 & 0.520 & 2.914 & 0.417 \\
\hline & $2400-2800$ & 11.07 & 0.0908 & 0.357 & 3.501 & 0.223 \\
\hline & $2800-3200$ & 7.0256 & 0.0080 & 0.031 & 5.516 & -1.752 \\
\hline & $3200-3459.94$ & 0.6924 & 0.0000 & 0.000 & 55.973 & 0.000 \\
\hline \multicolumn{7}{|c|}{ Stream Buffer } \\
\hline & $0-50$ & 6.909277 & 0.1010 & 0.397 & 5.609 & 0.800 \\
\hline & $50-100$ & 11.540977 & 0.0822 & 0.323 & 3.358 & 0.082 \\
\hline & $100-200$ & 12.625225 & 0.0602 & 0.237 & 3.070 & -0.319 \\
\hline & $>200$ & 7.680521 & 0.0110 & 0.043 & 5.046 & -1.526 \\
\hline \multicolumn{7}{|c|}{ Road Buffer } \\
\hline & $0-50$ & 2.087766 & 0.0366 & 0.144 & 18.563 & 0.982 \\
\hline & $50-100$ & 3.245363 & 0.0666 & 0.262 & 11.942 & 1.139 \\
\hline & $100-200$ & 5.371096 & 0.0423 & 0.166 & 7.216 & 0.183 \\
\hline & $>200$ & 28.051775 & 0.1089 & 0.428 & 1.382 & -0.525 \\
\hline \multicolumn{7}{|l|}{ Soil type } \\
\hline & $\mathrm{Bd} 34-2 \mathrm{bc}$ & 0.431 & 0 & 0 & 89.9211 & 0 \\
\hline & I-Bh-U-c & 38.325 & 0.2544 & 1.000 & 1.011 & 0.011 \\
\hline \multicolumn{7}{|l|}{ Landuse } \\
\hline & Cultivation & 11.1784 & 0.1536 & 0.604 & 3.467 & 0.739 \\
\hline & Forest & 23.6076 & 0.0320 & 0.126 & 1.642 & -1.577 \\
\hline & Bush & 1.7556 & 0.0190 & 0.075 & 22.076 & 0.500 \\
\hline & Settlement & 0.2904 & 0.0000 & 0.000 & 133.457 & 0.000 \\
\hline & Grassland & 1.5444 & 0.0492 & 0.193 & 25.095 & 1.580 \\
\hline & Airport & 0.0652 & 0.0005 & 0.002 & 594.417 & 0.158 \\
\hline & $\begin{array}{l}\text { Sand \& } \\
\text { Gravel }\end{array}$ & 0.0344 & 0.0000 & 0.000 & 1126.628 & 0.000 \\
\hline & River & 0.28 & 0.0000 & 0.000 & 138.414 & 0.000 \\
\hline \multicolumn{7}{|l|}{ Geology } \\
\hline & qtz-gns & 8.7852 & 0.0270 & 0.106 & 4.412 & -0.758 \\
\hline & gns-sch-qtz & 15.0324 & 0.0332 & 0.130 & 2.578 & -1.090 \\
\hline & sch-qtz & 14.9384 & 0.1942 & 0.763 & 2.594 & 0.683 \\
\hline
\end{tabular}




\section{Susceptibility index and validation}

The landslide susceptibility index in the study area ranged from -7.12 to 5.45 (Fig. 6). This range was classified into five susceptibility classes in arc GIS environment from very low to very high. It was observed the stream buffers, cultivated lands, geology and grasslands strongly influencing the landslide susceptibility of the area.

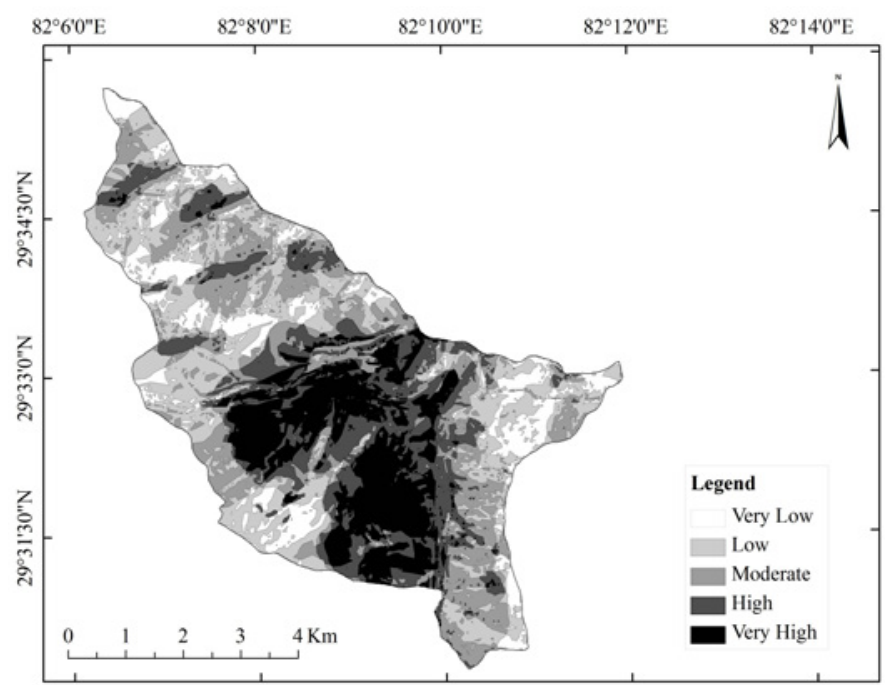

Fig. 6: Susceptibility map of the study area.

Nearly $37 \%$ of the study area falls into high susceptible (HS) and very high susceptible (VHS) zones (Table 2). And about $23 \%$ falls into moderate susceptible (MS) zones. Rest $40 \%$ of study area is occupied by low susceptible (LS) and very low susceptible (VLS) zones.

Table 2: Landslide density of susceptibility classes.

\begin{tabular}{|l|c|c|c|c|c|}
\hline $\begin{array}{l}\text { Susceptibility } \\
\text { Class }\end{array}$ & VLS & LS & MS & HS & VHS \\
\hline Class Area (a) & 4.95 & 10.45 & 9.01 & 7.35 & 6.65 \\
\hline $\begin{array}{l}\text { No. of } \\
\text { landslides (b) }\end{array}$ & 0 & 2 & 5 & 35 & 54 \\
\hline $\begin{array}{l}\text { Landslide Area } \\
\text { (c) }\end{array}$ & 0.0036 & 0.01 & 0.0244 & 0.0768 & 0.1396 \\
\hline $\begin{array}{l}\text { Landslide } \\
\text { Density (c/a) }\end{array}$ & 0.00073 & 0.00096 & 0.00271 & 0.01044 & 0.021 \\
\hline $\begin{array}{l}\text { Landslide } \\
\text { Density (b/a) }\end{array}$ & 0.00 & 0.19 & 0.55 & 4.76 & 8.12 \\
\hline
\end{tabular}

It was observed that in forested areas the landslide susceptibility is lower. More than $90 \%$ of landslides were occupied in VHS and HS zones. Thus, they have higher landslide densities 8.12 and 4.76 per $\mathrm{km}^{2}$ respectively (Table 2). Higher landslide densities in those susceptible classes make the results more valid.
The susceptibility map was validated by making success rate curve that measured area under the curve (AUC). The success rate showed 0.76 AUC (Fig. 7) that means the model has predictability of $76 \%$ in the study area. Onagh et al. (2012) found 0.762 AUC in their validation of model in Uttrakshi district north-western India. In Kulekhani watershed (Kayastha et al. 2013) the AUC for statistical index method was 0.7578 . Thus, the AUC obtained in this area is quite similar to that of other researches in Himalayas.

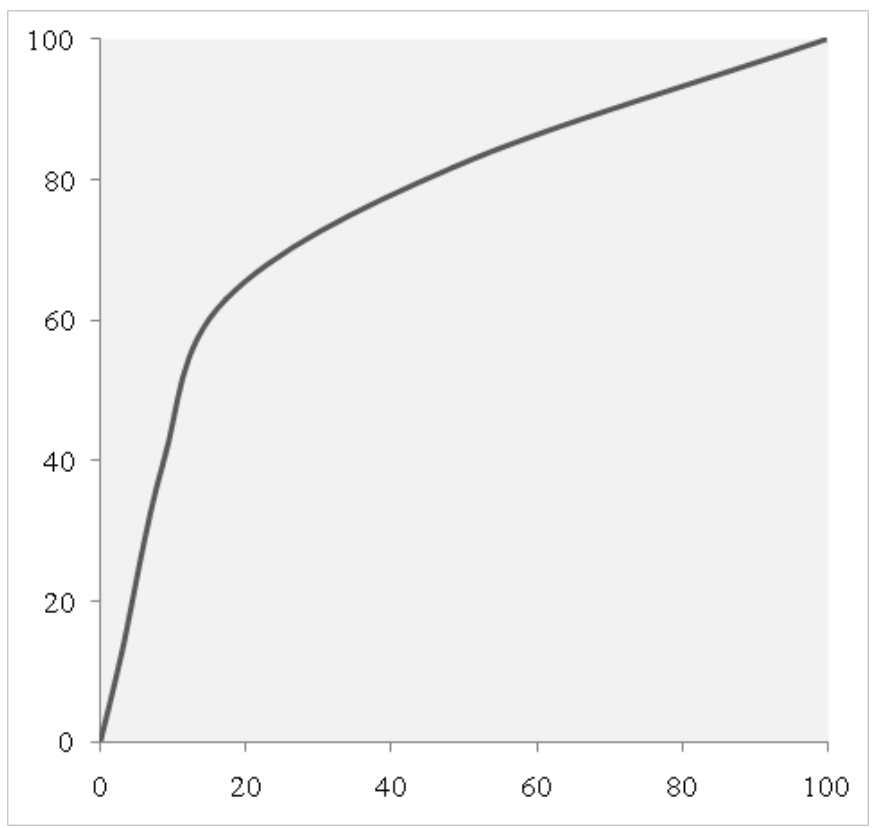

Fig. 7: Success rate curve for validation of the model.

\section{CONCLUSIONS}

The landslide susceptibility map of the study area was prepared using the method of van Westen (1997). The map shows higher susceptibility near the central part of the study area where the aspects are south and east, slopes are less than $30^{\circ}$ and weight values are positive. Other parameters for higher susceptibility are streams and road proximities, and rock types such as phyllite, schist and gneiss. Higher susceptibility is also observed in cultivated areas and grasslands where most households were located. Thus, the knowledge of landslide susceptibility in the area is highly important for development activities of the area in order to reduce future occurrences of slope failures.

\section{ACKNOWLEDGEMENTS}

Authors are very thankful to Strengthening Disaster Risk Management in Academia (Cooperation of Tribhuvan University, Central Department of Environmental Science and United Nations Development Programme) for providing grant to carry out this research. 


\section{REFERENCES}

Arita, K., Shiraishi, K., and Hayashi, D., 1984, Geology of western Nepal and a comparison with Kumaun, India. Jour. Fac. Sci., Hokkaido University. Series 4, Geology and mineralogy, v. 21(1), pp. 1-20.

Ayalew, L. and Yamagishi, H., 2005, The application of GISbased logistic regression for landslide susceptibility mapping in the Kakuda-Yahiko Mountains, central Japan. Geomorphology, v. 65, pp. 15-31.

Bhattarai, D., Tsunaki, R., and Mishra, A. N., 2002, Water and risk. Proc. Asia High summit, Nepal, Integrated Centre for Mountain Development, May 6-10, 2002.

Crozier, M. J. and Glade, T., 2004, Landslide hazard and risk: issues, concepts and approach. In T. Glade, M. Anderson and M. J. Crozier (eds.), Landslide Hazard and Risk, John Wiley \& Sons, Ltd, England, pp. 1-40.

Dahal, R. K., 2012, Rainfall-induced landslides in Nepal. Int. Jour. Japan Erosion Control Engineering, v. 5(1), pp. 1-8.

Dahal, R. K., Hasegawa, S., Masuda, T., and Yamanaka, M., 2006, Roadside slope failures in Nepal during torrential rainfall and their mitigation. In Disaster Mitigation of Debris Flows, Slope Failures and Landslides: proceedings of the INTERPRAVENT International Symposium Disaster Mitigation of Debris Flows, Slope Failures and Landslides, Universal Academy Press, Inc. Japan, pp. 503-514.

Dai, F. and Lee, C. F., 2002, Landslides on natural terrain: Physical characteristics and susceptibility mapping in Hong Kong. Mountain Research and Development, International Mountain Society, v. 22(1), pp 40-47.

Dangol, V., 2002, Landslide hazard mapping in Nepal: Case studies from Marin Khola (eastern Nepal) and Syangja district (western Nepal). In Disaster Mitigation of Debris Flows, Slope Failures and Landslides: proceedings of the INTERPRAVENT International Symposium Disaster Mitigation of Debris Flows, Slope Failures and Landslides, Universal Academy Press, Inc. Japan, v. 2, pp. 607-618.

Gerrard, J. and Gardner, R., 2002, Relationships between landsliding and land use in the Likhu Khola drainage basin, Middle Hills, Nepal. Mountain Research and Development, Int. Mountain Soc., v. 22(1), pp. 48-55.

Ghimire, M., 2010, Landslide occurrence and its relation with terrain factors in the Siwalik Hills, Nepal: Case study of susceptibility assessment in three basins. Natural Hazards, v. 56(1), pp. 299-320.

Hasegawa, S., Dahal, R. K., Yamanaka, M., Bhandary, N. P., Yatabe, R., and Inagaki, H., 2009, Causes of large-scale landslides in the Lesser Himalaya of central Nepal. Env. Geol., v. 57(6), pp. 14231434.

Kayastha, P., Dhital, M. R., and Smedt, F. D., 2013, Evaluation and comparison of GIS based landslide susceptibility mapping procedures in Kulekhani watershed, Nepal. Jour. Geol. Soc. India, v. 81, pp. 219-231.

Kayastha, P., Dhital, M. R., and Smedt, F. D., 2012, Evaluation of the consistency of landslide susceptibility mapping: A case from the Kankai Watershed in east Nepal. Landslides, v. 10, pp. 785-799.

Lee, S. and Min, K., 2001, Statistical analysis of landslide susceptibility at Yogin, Korea. Env. Geol., v. 40. pp. 1095-1113.

Lennartz, T., 2013, Constructing roads - constructing risks? Settlement decisions in view of landslide risk and economic opportunities in western Nepal. Mountain Research and Development, Int. Mountain Soc., v. 33 (4), pp. 364-371.

Ministry of Environment, 2010, Climate change vulnerability mapping for Nepal. Kathmandu, Nepal, pp. 6-34.

Montomoli, C., Iaccarino, S., Carosi, R., Langone, A., and Visonà, D., 2013, Tectonometamorphic discontinuities within the Greater Himalayan Sequence in western Nepal (Central Himalaya): Insights on the Exhumation of Crystalline Rocks. Tectonophysics, v. 608, pp. 13491370 .

Nepal Hazard Risk Assessment; Part 1: Hazard Assessment. Asian Disaster Preparedness Center (ADPC); Norwegian Geotechnical Institute (NGI); Centre for International Studies and Cooperation (CECI). (Retrieved on December 24, 2014, from webpage, National Risk Reduction Consortium (NRRC) flagship 2 website: (http://www. flagship2.nrrc.org.np/sites/default/files/knowledge/ Nepal\%20Hazard\%20Risk\%20Assessment $\% 20$ Part\%201.pdf )

Okino, T., and Satoh, Y., 1986, Morphology, Physics, Chemistry and Biology of Lake Rara in west Nepal. Hydrobiologia, v. 140 , pp. 125-133.

Onagh, M., Kumra, V. K., and Rai, P. K., 2012, Landslide susceptibility mapping in a part of Uttarakashi District (India) by Multiple Linear Regression Method. Int. Jour. Geology, Earth and Environmental Sciences, v. 2(2), pp. 102-120.

Poudyal, C. P., 2012, Landslide susceptibility analysis using Decision Tree Method, Phidim, eastern Nepal. Bull. Depart. Geol., Tribhuvan University, Nepal, v. 15, pp. 69-76.

Sarkar, S., Kanungo, D. P., Patra, A. K., and Kumar, P., 2006, GIS based landslide susceptibility mapping - a case study in Indian Himalaya. In: Disaster Mitigation of Debris Flows, Slope Failures and Landslides: proceedings of the INTERPRAVENT International Symposium Disaster Mitigation of Debris Flows, Slope Failures and Landslides, Universal Academy Press, Inc. Japan, pp. 617-624. 
Upreti, B. N., 2001, The physiography and geology of Nepal and their bearing on the landslide problem. In: L. Tainchi, S. R. Chalise, and B. N. Upreti, (eds.), Landslide Hazard Mitigation in the Hindu KushHimalayas, International Centre for Integrated Mountain Development, pp. 30-50. van Westen, C. J., Rengers, N., and Soeters, N., 2003, Use of geomorphological information in indirect landslide susceptibility assessments. Natural Hazards, v. 30, pp. 399-419.

Varnes, D. J., 1984, Landslide hazard zonation: a review of principles and practice. United Nations Educational, Scientific and Cultural Organization (UNESCO), Paris, $63 \mathrm{p}$. 